\title{
The Proteases of Plants (III).
}

\author{
BY \\ S. H. VINES, F.R.S., \\ Sherardian Professor of Botany in the University of Oxford.
}

$\mathrm{N}$ the series of papers (Nos. 1-5) that I have contributed during the last
three years to the Annals of Botany, I have given the results of a large number of experiments which suffice to prove that proteases are very widely distributed both in the body of the individual plant and in the vegetable kingdom : so widely, indeed, that further investigation may be expected to show, in the course of time, that they are present in every part of every plant at some stage or other of its development.

With regard to the nature of the proteases, I have shown that they are not, as had been previously thought, necessarily such as can act upon the higher proteids (fibrin or albumin). Though I have been able to add to the number of the plants whose juices can effect fibrin-digestion (see 5, p. I6I), a more important contribution to the knowledge of the subject is the discovery of a protease which is without action on the higher proteids but proteolyses the simpler proteids, notably albumoses and peptones, as indicated by the application of the tryptophane-test (2, p. 262). This protease thus belongs to the group of the ereptases, finding its nearest analogue in the erepsin of the animal body: but with this difference, that whilst animal erepsin is most active in a slightly alkaline medium, the erepsin of plants is most active in a slightly acid medium (see 4, p. $3^{\mathrm{I}} 4$ ). The erepsin is of more general occurrence in plants than the protease that digests fibrin; as is shown by the fact that in many cases the juices or prepared extracts of different parts of various plants that were found to proteolyse albumoses or peptones actively had no digestive action on fibrin. No case was, however, observed of the digestion of fibrin, whether by the juice, an extract, or the tissue of a part of a plant, without the occurrence of tryptophane among the products. In other words, whilst peptolysis can take place without fibrin-digestion (peptonization), fibrindigestion has not yet been found to take place without peptolysis. This justifies the statement that the peptolytic enzyme may occur independently, whereas there is no evidence of the independent existence of a purely

[Annals of Botany, Vo1. XIX. No. LXXIV. April, 1905.] 
fibrin-digesting (or peptonizing) enzyme: a statement that raises the important question of the nature of the latter enzyme, to the discussion of which this paper is devoted.

\section{The Nature of the Fibrin-digesting Protease.}

The original view, propounded on the discovery of proteid-digestion by plants (1874), was that the active enzyme is allied to the pepsin of the higher animals. For instance, Darwin (6), speaking of Dionaea, says : 'When a leaf closes on any object, it may be said to form itself into a temporary stomach; and if the object yields ever so little animal matter ... the glands on the surface pour forth their acid secretion, which acts like the gastric juice of animals.' Similarly, Sir Joseph Hooker (7) said, with regard to Nepenthes: 'From the observations it would appear probable that a substance acting as pepsin does is given off from the inner wall of the pitcher, but chiefly after placing animal matter in the acid fluid': and von Gorup-Besanez and Will (8) described the pitcher-liquid of Nepenthes as 'a vegetable solution of pepsin.' Von Gorup-Besanez did not actually use the word 'pepsin' in the account of his discovery (9) of a peptonizing ferment in germinating seeds (Malt, Vetch, \&c.), but his observations suggest that this was his idea of its nature.

This view was a fair inference from the fact that the higher proteids had been observed, in these cases, to be digested by an acid liquid; and was supported by the discovery, made by von Gorup-Besanez, that peptones are formed in the process. Not only did he discover this, but he went on to inquire whether or not the peptones so formed underwent further change (peptolysis). In an experiment with extract of Vetch seeds acting on fibrin swollen with $0.2 \% \mathrm{HCl}$, he looked for, but failed to find, leucin, tyrosin, asparagin, or asparaginic acid among the products of digestion. This negative result must have been a disappointment to the investigator, since the object of his research was to account for the presence of leucin and asparagin in seedlings, and it had occurred to him that these substances might possibly be formed in the germinating seed by a peptolytic process analogous to the pancreatic digestion of proteids in the animal body. However, the idea seemed untenable in the face of the above experiment, so von Gorup-Besanez contented himself with simply recording the presence in these seeds of 'peptonbildende Fermente.'

Within a comparatively short time, the pepsin-theory of the nature of the fibrin-digesting protease had to make way for the trypsin-theory by which it was replaced. The first step in this direction was the observation made by Wurtz (10), in his investigation of papaïn, that this substance could digest in neutral and alkaline as well as in acid media; and on this account he regarded it as allied rather to the pancreatin (i.e. 
trypsin) than to the pepsin of animals. This view was further supported by Martin's discovery (11) of leucin and tyrosin among the products of papaïn-digestion. On this ground Martin concluded that 'papaïn is a proteolytic ferment acting almost exactly like trypsin.' In a subsequent paper (12) Martin made the following interesting remark: 'Why, indeed, there should be a pepsin-like ferment in some plants and a trypsin-like in others is as much a problem as why there should be the two forms in mammals.' To what extent this problem has now been solved will appear in the sequel. In the meantime it may be generally asserted that the result of nearly all subsequent investigation has been to establish the 'tryptic' action of vegetable enzymes. Without quoting every individual case, it may be mentioned, for instance, that Green found (13) in the seed of the Lupin (L. hirsutus) ' a proteolytic ferment, working in an acid medium, capable of converting fibrin into peptone, leucin, and tyrosin.' With regard to the protease of the Pineapple (Ananas sativus), Chittenden wrote (14): "The results indicate that the ferment is more nearly related to trypsin than to pepsin, in that not only are proteoses and peptone formed by its action, but also leucin and tyrosin.' In 5902 I summarized the conclusion to be drawn, as well from the researches of others as from my own, as follows (1, p. I9):- 'The additional instances that I have now given of the production of tryptophane, selected as they are from various classes and from different parts of plants, bear out my previously expressed opinion that the proteolytic enzymes of plants in general are essentially "tryptic." This statement will at any rate hold good until definite evidence is adduced to prove the existence of a "peptic " enzyme."

The trypsin-theory was not, however, generally accepted without some demur. Thus Clautriau affirmed (15) that the enzyme of the pitcher-liquid of Nepenthes is a pepsin : but in my reply (16) I pointed out that this assertion must be incorrect, inasmuch as I had detected tryptophane among the products of Nepenthes-digestion. Again, Mendel and Underhill (17) made the statement that their observations indicate 'that papain belongs to a class of enzymes which differs somewhat in type from the two proteolytic enzymes that have received most careful investigation in the past, viz. pepsin and trypsin. While the products of the papaindigestion of proteids resemble quite closely those of pepsin, so far as these have been examined in detail, the enzyme differs from ordinary animal pepsin in that it acts readily in both neutral and alkaline media. On the other hand, although papain is comparable with trypsin in exerting a solvent action in fluids of various reactions, the failure to form leucin, tyrosin, and tryptophane in appreciable quantities - at least under conditions in which they are readily formed in large quantities by other tryptic enzymes - places it in a class of its own for the present.' In the course of special experiments to investigate these results $(3, \mathrm{p} .605)$, I ascertained that the 
reason why leucin, tyrosin, and tryptophane were not found by Mendel and Underhill was that sodium fluoride $\left(\mathrm{NaF} \mathrm{I}^{\%}\right.$ ), which they employed as the antiseptic, prejudicially affects the digestive activity of most samples of papain in that it retards or inhibits peptolysis but not peptonization. I was thus able to confirm the accuracy of Mendel and Underhill's observations, though I showed that they had been somewhat misinterpreted.

Their observations struck me as being of singular importance; in fact they suggested to me those further investigations into the nature of plantproteases which have led me to the new view that $I$ have already expressed with reference to certain special cases (see 5, p. I57), and that I now propound more comprehensively and in fuller detail as an advance upon the trypsin-theory.

The actual starting-point of the train of thought was the discovery of erepsin, to which I have already alluded (see p. I II). The fact that this protease was found to be present in various parts of different plants, unassociated with a fibrin-digesting enzyme, suggested the possibility that in the cases in which a juice or an extract both peptonized and peptolysed, this complete proteolysis might be effected, not by a single 'tryptic' enzyme, as was generally supposed, but by two distinct proteases; the one essentially peptolytic, erepsin in fact; the other purely fibrin-digesting or peptonizing, a pepsin. In a word, my idea was that the assumed 'vegetable trypsin' might be a mixture of an ereptic with a peptic enzyme. The known facts of digestion could be accounted for equally well on either hypothesis : the process and the products of digestion would be the same in either case. What was wanted for a decision between the two hypotheses was some means of analysing this supposed mixture, so as to separate the two proteases, either actually or, at any rate, in their action; and I seemed to have obtained a clue to the latter mode of analysis in the observations of Mendel and Underhill as explained by the results of my re-examination of them. The behaviour of papain in presence of $\mathrm{NaF}$ may be explained, on the assumption of a single 'tryptic' enzyme, by supposing that this protease is so acted upon by $\mathrm{NaF}$ that its peptolysing activity is inhibited; its peptonizing, fibrin-digesting, activity remaining unimpaired. But it may be urged against this supposition, and with considerable force, that when a protease is prejudicially affected by any agent or condition, presumably all forms of its activity suffer equally. This supposition is, in fact, less reasonable than the assumption that two distinct proteases are present, and that the arrest of the peptolytic action of papain by $\mathrm{NaF}$ is due to the inhibition of the peptolytic enzyme (erepsin). This clue I have endeavoured to follow up.

In the first place I sought for other instances of the differential action of various antiseptics, but without adequate success; papain is so far the only clear case of the kind that I have observed. I next tried the method 
of solubility: that is, I prepared extracts of various plants and parts of plants, either with distilled water or with $2 \%$ solution of common salt $(\mathrm{NaCl})$, and compared their digestive activities. This method, which is, of course, only applicable when solid material has to be dealt with, gave interesting results in the case of Yeast (Saccharomyces Cerevisiae) and of the Mushroom (Agaricus campestris). I found in both cases (4) that a rapidly prepared watery extract could not digest fibrin, though it peptolysed Witte-peptone : on the other hand, a rapidly prepared extract made with $\mathrm{NaCl}$-solution digested fibrin within 24 hours, and also peptolysed Witte-peptone. From these facts I inferred that there are two proteases in these plants: one, readily soluble in water, digesting peptone but not fibrin: the other, less soluble in water, digesting fibrin. The former cannot well be anything but erepsin: as to the latter, the method gave no certain indication whether it were a pepsin or a trypsin, inasmuch as the $\mathrm{NaCl}$-solution dissolved out not only the peptonizing enzyme, but the erepsin as well. A decisive result, on this method, could only be attained by ensuring the removal by water of the whole of the erepsin, leaving the peptonizing enzyme behind alone : but this I had not succeeded in doing to my satisfaction. Consequently, I was content to regard the peptonizing enzyme, provisionally, as a trypsin, in accordance with the prevalent view $\left(4\right.$, p. $\left.3^{\text {I } 5}\right)$.

I then sought for another method that should be more decisive in its results and of more general application. In the before-mentioned experiments with Yeast and the Mushroom, I had incidentally observed that peptolysis and fibrin-digestion were effected in much the same manner, but not to the same degree, by the reaction of the liquid, whether acid, alkaline, or neutral: it appeared, in fact, that a physiological analysis might be effected in this way. I applied this method, in the first instance, to the investigation of papain (5), with results that led me to the conclusion that this substance contains two proteases, an erepsin, and a fibrin-digesting but not peptolytic enzyme which can only be regarded as of the nature of a pepsin. Since writing that paper, I have applied the method to the Pineapple, Yeast, the Mushroom, Malt, Hyacinth-bulb, and the pitcherliquid of Nepenthes; in fact, to most of the plants which I knew to be capable of digesting fibrin, and in every case with confirmatory results.

The following is a selection from the very numerous experiments : for the sake of completeness I introduce some made with papaïn, although I have already dealt with that substance (5). I may explain that an important feature in my method is the simultaneous presentation of fibrin and Witte-peptone for digestion. Moreover, the essential point for a successful experiment is to add acid or alkali in due proportion to the enzyme-strength of the digesting liquid. When the reaction was artificially varied, $\mathrm{HCl}$ was the acid used, and $\mathrm{Na}_{2} \mathrm{Co}_{3}$ the alkali. The antiseptic 
employed in each case was that which I had found by previous experience to affect proteolysis as little as possible: in some cases the antiseptic was varied in different experiments for the sake of comparison.

\section{Carica Papaya.}

4 grms. of papaïn (Christy) were extracted for a couple of hours with $200 \mathrm{cc}$. distilled water: 4 grms. of Witte-peptone were added, and after standing for 3 hours the liquid was decanted from the undissolved residue: the liquid was faintly acid : $\mathrm{HCN}$ to $0.2 \%$ was added as the antiseptic. $40 \mathrm{cc}$. of the liquid were put into each of 5 bottles with $0.2 \mathrm{grm}$. of fibrin, and treated respectively as follows: No. $\mathbf{I}$, nothing added; No. $2, \mathrm{Na}_{2} \mathrm{CO}_{3}$ to $0.5 \%$ (alkaline); No. $3, \mathrm{Na}_{2} \mathrm{CO}_{3}$ to $\mathrm{I} \%$; No. 4 , $\mathrm{HCl}$ to $0.2 \%$; No. $5, \mathrm{HCl}$ to $0.3 \%$.

After 24 hours' digestion in the incubator at $38^{\circ} \mathrm{C}$. the fibrin had disappeared in all the bottles: the tryptophane-reactions were:-

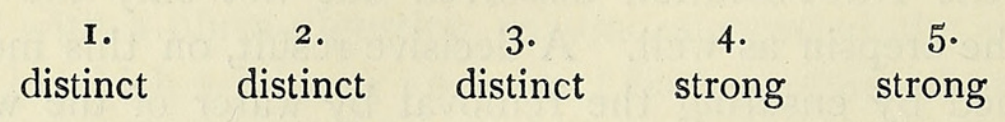

Another experiment, in which half the quantity of papain was used, gave similar results.

Conclusion: fibrin-digestion not materially affected by difference of reaction: peptolysis diminished by neutral or alkaline reaction.

In the following experiment no Witte-peptone was added, but the quantity of fibrin was increased to $\frac{1}{2} \mathrm{grm}$., and the limits of alkalinity and acidity were extended: in all other respects the conditions were as in the preceding experiment: the bottles were :-No. I, natural reaction (nearly neutral); No. $2, \mathrm{Na}_{2} \mathrm{CO}_{3}$ to $\mathrm{I} \cdot 5 \%$; No. 3 , $\mathrm{HCl}$ to $0.2 \%$; No. $4, \mathrm{HCl}$ to $0.5 \%$.

After 24 hours' digestion the fibrin had disappeared in all the bottles except No. 4, where it did not seem to have been materially reduced: the tryptophanereactions were:-

$\begin{array}{cccc}\text { I. } & 2 . & 3 . & 4 \cdot \\ \text { distinct } & \text { none } & \text { marked } & \text { none }\end{array}$

Conclusion. The results given by bottles Nos. $1-3$ confirm the conclusion drawn from the preceding experiments: it appears that the addition of $\mathrm{Na}_{2} \mathrm{CO}_{3}$ to $\mathrm{I} \cdot 5 \%$ inhibited peptolysis but did not materially affect fibrin-digestion. With regard to bottle No. $4, \mathrm{HCl}$ to the extent of $0.5 \%$ completely arrested both processes.

These experiments demonstrate the differential effect of alkalinity on the activity of papain, diminishing or arresting peptolysis but not fibrindigestion. I interpret this to mean that papain contains a fibrin-digesting enzyme having a wide range of action, limited in one direction by $0.5 \% \mathrm{HCl}$, and in the other by a greater amount than $\mathrm{I} \cdot 5 \% \mathrm{Na}_{2} \mathrm{Co}_{3}$; as well as a peptolytic enzyme of narrower range, limited by $0.5 \% \mathrm{HCl}$ on the one hand and by $1.5 \% \mathrm{Na}_{2} \mathrm{Co}_{3}$ on the other. I may add that these experimental results agree on the whole with those previously recorded $(5$, p. I 55 ; 
3, p. 605). It is not surprising that the peptolytic enzyme should have been found to be less active in neutral or alkaline liquid than in acid, when it is remembered that the latex and the juices of the Papaw are acid.

I have not attempted to determine the limits of alkalinity and acidity for other samples of papaïn : no doubt they would be found to vary considerably. But I know from previous experiments that the nature of the differential effect is essentially the same in all, under the same conditions.

\section{Ananas sativus.}

$40 \mathrm{cc}$. of the expressed juice of a ripe Pineapple were put into each of 5 bottles, $2 \%$ of Witte-peptone having been previously added : $0.3 \mathrm{grm}$. fibrin was put into each bottle. To 2 of the bottles $\mathrm{Na}_{2} \mathrm{CO}_{3}$ was gradually added to the extent of $7 \cdot 5 \%$, when a definitely alkaline reaction was attained: the contents of 2 bottles were left at natural acidity: to the fifth bottle $\mathrm{HCl} 0.2 \%$ was added. To a naturally acid bottle and to an alkaline bottle $\mathrm{HCN} 0.2 \%$ was added: to a similar pair of bottles $\mathrm{NaF}$ I \% was added: there were thus 4 bottles containing an antiseptic, but no antiseptic was added to the $\mathrm{HCl}$ bottle.

After 24 hours' digestion in the incubator at $38^{\circ} \mathrm{C}$. the fibrin had disappeared in all the bottles: the tryptophane-reactions were :-

$$
\begin{array}{ccccc}
H C N \text { acid. } & H C N \text { alk. } & \text { NaF acid. } & \text { NaF alk. } & H C l . \\
\text { marked } & \text { none } & \text { strong } & \text { none } & \text { strong }
\end{array}
$$

Conclusion: peptolysis, but not fibrin-digestion, completely inhibited by alkalinity.

A corresponding experiment made with juice diluted with equal volume of distilled water gave results of the same nature. In yet another experiment in which $\mathrm{Na}_{2} \mathrm{CO}_{3}$ was added to $2.5 \%$ (reaction still acid) and to $5 \%$ (reaction slightly alkaline), a faint tryptophane-reaction was observed, showing that peptolysis was not altogether inhibited.

The effect of alkalinity upon peptolysis is further demonstrated by the following experiment, in which three degrees of alkalinity were compared, and in which Wittepeptone was not added until after the completion of fibrin-digestion.

$50 \mathrm{cc}$. of juice were placed in each of 4 bottles with $\mathrm{I} \%$ toluol and $\frac{1}{2} \mathrm{grm}$. fibrin: No. I, contents of natural acidity; No. 2, slightly alkaline by addition of $\mathrm{Na}_{2} \mathrm{CO}_{3}$ to $4 \%$; No. 3 , more alkaline, $\mathrm{Na}_{2} \mathrm{CO}_{3} 6 \%$; No. 4, strongly alkaline, $\mathrm{Na}_{2} \mathrm{CO}_{3} 8 \%$.

After 24 hours' digestion the results were:-

$\begin{array}{llccl} & \text { I. } & 2 . & 3 . & 4 . \\ \text { fibrin } & \text { nearly gone } & \text { gone } & \text { gone } & \text { attacked } \\ \text { tryptophane-reaction } & \text { faint } & \text { faint } & \text { none } & \text { none }\end{array}$
after 48 hours' digestion :-

$\begin{array}{lllll}\text { fibrin } & \text { gone } & - & - & \text { nearly gone } \\ \text { tryptophane-reaction } & \text { faint } & \text { faint } & \text { none } & \text { none }\end{array}$


to each bottle $0.3 \mathrm{grm}$. Witte-peptone (about I \%) now added: after 24 hours' further digestion :-

$\begin{array}{lcccc} & \text { I. } & 2 . & 3 \cdot & 4 . \\ \text { fibrin } & - & - & - & \text { gone } \\ \text { tryptophane-reaction } & \text { strong } & \text { distinct } & \text { none } & \text { none }\end{array}$

These results are in agreement with those obtained with papain, but are even more striking in the differential effect of alkalinity upon fibrin-digestion and peptolysis: the former process was fairly active after the addition of $8 \% \mathrm{Na}_{2} \mathrm{Co}_{3}$, whilst the latter was only slightly active with $4 \% \mathrm{Na}_{2} \mathrm{Co}_{3}$, a degree of alkalinity not far from neutralization.

\section{Saccharomyces Cerevisiae.}

The experiments were made with the dried, granulated Yeast mentioned in a previous paper (4, p. 293).

Io grms. of the dried Yeast, ground fine, were rubbed in a mortar with about $200 \mathrm{cc}$. of $2 \% \mathrm{NaCl}$-solution, and after standing for an hour or so, the mixture was put upon a filter. After 3 hours' filtration an acid liquid was obtained giving no tryptophane-reaction : to $200 \mathrm{cc}$. of the liquid 2 grms. of Witte-peptone were added, and toluol to I \% : $40 \mathrm{cc}$. were now put into each of 5 bottles treated as follows :No. I, left at natural acidity; No. 2, added $\mathrm{Na}_{2} \mathrm{CO}_{3}$ to $\mathrm{I} \cdot 5 \%$ (alkaline); No. 3 , $\mathrm{Na}_{2} \mathrm{CO}_{3}$ to $2 \%$; No. $4, \mathrm{HCl}$ to $0.2 \%$; No. $5, \mathrm{HCl}$ to $0.5 \%: 0.2 \mathrm{grm}$. of fibrin was added to each bottle.

After 24 hours' digestion the results were :-

I.

fibrin gone

tryptophane very strong
2.

unaltered

very strong
3. unaltered strong
4. unaltered strong
5 . unaltered faint after 48 hours' digestion :-

fibrin as before; tryptophane-reaction still faint in No. 5 .

Conclusion: peptolysis active through wide range of reaction, limited in the acid direction by $0.5 \% \mathrm{HCl}$ : fibrin-digestion inhibited by all the variations from natural acidity.

These results are in general agreement with those recorded in the paper already referred to $(4, \mathrm{pp} .299,304)$, allowing for the fact that the two sets of experiments were made with two different samples of dried Yeast, of which the one used in the above experiment showed itself to be the more active. Combining the two sets of results, the limits of proteolytic activity of a $5 \%$ Yeast extract $(\mathrm{NaCl})$ are approximately-for peptolysis of Wittepeptone, from about $3 \% \mathrm{Na}_{2} \mathrm{Co}_{3}$ to about $0.5 \% \mathrm{HCl}$; for fibrin-digestion, from about $\mathrm{I} \% \mathrm{Na}_{2} \mathrm{Co}_{3}$ to about $0.1 \% \mathrm{HCl}$; so that the range of reaction is much more extended for peptolysis than for fibrin-digestion.

The chief interest of these results with Yeast lies in the comparison of 
them with those obtained with papain and with the Pineapple. Reference to those results shows, in the first place, that whilst in those cases it was possible to arrest peptolysis, in the case of Yeast it was possible to arrest fibrin-digestion. This is an important piece of evidence in the inquiry into the nature of 'vegetable trypsin': the arrest of one of the two processes would have been a suggestive fact, but the arrest of both of them, in different material, is a weighty argument. Again, in papain and in the Pineapple, peptolysis was found to have a narrower reaction-range than fibrin-digestion ; whereas in Yeast the contrary is the case. I will defer any discussion on this point to the end of this paper. The experiments with other plants that yet remain to be described give results agreeing in the main with those of Yeast.

\section{Agaricus campestris.}

The material used consisted of dried Mushrooms ground to fine powder.

3 grms. of the powder were extracted with $120 \mathrm{cc}$. of $2 \% \mathrm{NaCl}$-solution, and the mixture was placed on a filter for some hours in the cold. The filtrate was a dark, slightly acid liquid, giving no tryptophane-reaction: to it was added $\mathbf{I}$ grm. Wittepeptone, and toluol to about $\mathrm{I} \% 40 \mathrm{cc}$. were put into each of 3 bottles: the contents of No. I were left at natural reaction; those of No. 2 were made alkaline with $\mathrm{Na}_{2} \mathrm{CO}_{3} 0.5 \%$; those of $\mathrm{No} .3$ were acidified with $\mathrm{HCl} 0 . \mathrm{I} \%$ : to each bottle $0.2 \mathrm{grm}$. fibrin was added.

After 24 hours' digestion in the incubator at $39^{\circ} \mathrm{C}$. the results were :-

I.

2.

3 .

$\begin{array}{llll}\text { fibrin } & \text { gone } & \text { unaltered } & \text { unaltered } \\ \text { tryptophane } & \text { marked } & \text { strong } & \text { distinct }\end{array}$

after 48 hours' digestion :-

$\begin{array}{llll}\text { fibrin } & - & \text { unaltered } & \text { unaltered } \\ \text { tryptophane } & - & - & \text { marked }\end{array}$

Conclusion: peptolysis somewhat retarded by acid, promoted by alkali : fibrindigestion arrested by deviation from normal reaction, whether acid or alkaline.

Here again, as in the case of Yeast, it is fibrin-digestion that is the more affected by increased acidity or by alkalinity, the differential action being well marked.

\section{Hordeum sativum.}

In view of Weis's (18) important investigation of the proteolysis of Malt, I took the opportunity of making some experiments upon it. It offers this disadvantage, that the extracts give a tryptophane-reaction to begin with, as might be expected. By previous experiment I had 
ascertained that $\mathrm{NaCl}$-extracts digest fibrin more actively than watery extracts.

200 grms. of green Malt (I I days' germination) were ground to pulp in the machine, and were extracted for 3 hours with $500 \mathrm{cc}$. of $2 \% \mathrm{NaCl}$-solution, and then left on the filter in a cold room for several hours. The filtered liquid was distinctly acid, and gave a distinct tryptophane-reaction. To $200 \mathrm{cc}$. of the liquid $4 \mathrm{grms}$. of Witte-peptone were added, as also toluol to about I \%. $40 \mathrm{cc}$. of the extract were placed in each of 6 bottles : bottle No. I contained extract with toluol only; bottles Nos. 2-6, extract with Witte-peptone and toluol; into each bottle was put $0.3 \mathrm{grm}$. fibrin. No further additions were made to Nos. I and 2 : to No. $3, \mathrm{Na}_{2} \mathrm{CO}_{3}$ was added to I \% (alkaline reaction); to No. $4, \mathrm{Na}_{2} \mathrm{CO}_{3}$ to $2 \%$; to No. $5, \mathrm{HCl}$ to $0 . \mathrm{I} \%$; to No. $6, \mathrm{HCl}$ to $0.2 \%$.

After 24 hours in the incubator at $45^{\circ} \mathrm{C}$, a temperature selected in accordance with Weis's observations, the results were :-

I.

$$
\left\{\begin{array}{l}
\text { nearly } \\
\text { gone }
\end{array}\right\}
$$

tryptophane marked

and after 48 hours :-

fibrin gone gone

tryptophane marked
2.

unaltered very strong
3 .

\begin{abstract}
unaltered
\end{abstract}
marked
4 .

6.

5 .

unaltered marked strong very strong

Conclusion: fibrin-digestion inhibited by alkalinity, and by $0.2 \% \mathrm{HCl}$ : peptolysis active within the same range of reaction, though it must be remembered that the extract gave a distinct tryptophane-reaction to begin with.

I observed that the reaction of the $\mathrm{Na}_{2} \mathrm{CO}_{3} 2 \%$ bottle in this experiment changed from alkaline to acid, as commonly occurs in vegetable extracts, and consequently makes it difficult to neutralize them or to make them alkaline permanently. In order, therefore, to confirm and extend the result as to the effect of alkalinity upon the peptolytic activity of Malt-extract, I made this further experiment, using a weaker extract and larger percentages of $\mathrm{Na}_{2} \mathrm{CO}_{3}$.

$5 \circ$ grms. of Malt ground to pulp were extracted with 250 cc. of $2 \% \mathrm{NaCl}-$ solution, and filtered, the whole process occupying about 6 hours : the acid filtrate gave a distinct tryptophane-reaction: to the $\mathbf{r} 60 \mathrm{cc}$. of filtrate obtained, $3 \mathrm{grms}$. of Witte-peptone were added, and $\mathrm{HCN}$ to $0.2 \%$ : $40 \mathrm{cc}$. were put into each of 4 bottles, as follows:-No. I, left at natural acidity; to No. $2, \mathrm{Na}_{2} \mathrm{CO}_{3}$ to $2 \%$ was added ; to No. $3, \mathrm{Na}_{2} \mathrm{CO}_{3}$ to $3 \%$; to No. $4, \mathrm{Na}_{2} \mathrm{CO}_{3}$ to $4 \%$; the contents of all the bottles (except No. I) were more or less strongly alkaline. After 24 hours' digestion at $40^{\circ} \mathrm{C}$. the reactions of Nos. 2,3 , and 4 were still alkaline: the tryptophane-reactions were :-

$$
\begin{array}{cccc}
\text { I. } & \text { 2. } & 3 \cdot & 4 \cdot \\
\text { strong } & \text { distinct } & \text { distinct } & \text { marked }
\end{array}
$$


After 24 hours' further digestion the reaction of No. 2 had become slightly acid, those of Nos. 3 and 4 remaining alkaline : the tryptophane-reactions were :-

$\begin{array}{cccc}\text { I. } & 2 . & 3 . & 4 \cdot \\ \text { strong } & \text { strong } & \text { strong } & \text { marked }\end{array}$

After 24 hours' further digestion the reaction was still alkaline in Nos. 3 and 4 : the tryptophane-reaction had become very strong in Nos. $\mathbf{x}$ and 2 , and was unchanged in Nos. 3 and 4.

Conclusion: peptolysis not inhibited by distinct alkalinity, though certainly retarded; nor is the intensity of the tryptophane-reaction diminished by longcontinued digestion with alkali.

The second experiment confirms the first as regards peptolysis. It appears that though alkalinity retards peptolysis to begin with, the process eventually attains considerable activity.

Taking the results of the two experiments together, it is clear that peptolysis has a wider reaction-range than fibrin-digestion: in fact the latter process is confined, as in Yeast, to about natural acidity.

The comparison of my results with those of Weis raises points of considerable interest. Our methods of experiment differed in almost every respect: Weis worked with a strong aqueous extract, I with a more dilute $\mathrm{NaCl}$-extract : he employed mainly vegetable proteids (glutin and legumin) as the material for digestion, I used fibrin and Witte-peptone of animal origin; and the means of estimating digestive activity were altogether different. Yet we both come to the conclusion that two distinct proteases exist in Malt. His statement is that two stages can be distinguished in the proteolysis effected by Malt, a peptic stage and a tryptic stage; and that these two stages are the result of the action of two enzymes, a peptase and a tryptase, since they are diversely affected by external conditions. I regard the two enzymes as being respectively a peptase and an ereptase (not a tryptase): but the difference between us is more apparent than real. For, on another page of his work (18, p. 234), Weis discusses the action of the tryptase, and raises the question whether or not it can peptonize as well as peptolyse. On the analogy of animal trypsin, this might, he admits, be the case : but he expresses a doubt if animal trypsin be really a single protease: so he leaves the question open. However, in a footnote, he alludes to Cohnheim's discovery of erepsin in a manner suggesting that he thinks his 'tryptase' may be an enzyme of that nature.

We agree, not only in this cardinal point, but also generally in the conclusion that alkalinity retards peptolysis: though my experiments go somewhat further than his, and show that in an alkaline liquid peptolysis is eventually active. The reason of this lies in the difference in the relative duration of our experiments. Weis's determinations were made after only 2 hours' digestion; mine after at least 24 . Had his experiments been more prolonged, his results would, no doubt, have been in accordance with mine. 


\section{Hyacinthus orientalis.}

In a previous paper (2) I stated that the bulb of the Hyacinth can peptolyse Witte-peptone (p. 25I), and can digest fibrin in an alkaline medium (p. 254). More recently (4, p. 316) I have shown that both peptolysis and fibrin-digestion were effected by a $2 \% \mathrm{NaCl}$-extract of the bulb, but less actively in a liquid to which $0.1 \% \mathrm{HCl}$ had been added than in a liquid of natural acidity or slightly alkaline. I now give the results of new experiments made with the view of inducing differential effects.

It may be explained that strong $\mathrm{NaCl}$-extracts (3 parts of water to I of bulb) are so active, in both peptolysis and fibrin-digestion, that it is convenient to prepare them more dilute.

50 grms. of mashed bulb were extracted for a couple of hours with $200 \mathrm{cc}$. $2 \% \mathrm{NaCl}$-solution: the liquid was then strained off through muslin, and was found to be slightly acid and to give a faint tryptophane-reaction. 4 grms. of Wittepeptone were added to it, and toluol to I \% $40 \mathrm{cc}$. of the mixture were put into each of 5 bottles, treated as follows:-No. $\mathrm{r}$, nothing added; No. $2, \mathrm{Na}_{2} \mathrm{CO}_{3}$ to I. $5 \%$; No. $3, \mathrm{Na}_{2} \mathrm{CO}_{3}$ to $2 \%$; No. $4, \mathrm{HCl}$ to $0.2 \%$; No. $5, \mathrm{HCl}$ to $0.4 \%$ : to each bottle $0.3 \mathrm{grm}$. fibrin was added.

After 24 hours' digestion $\left(40^{\circ} \mathrm{C}\right.$.) the results were :-

\begin{tabular}{llllll} 
& \multicolumn{1}{c}{ I. } & 2. & 3. & \multicolumn{4}{c}{} & 5. \\
fibrin & gone & gone & gone & partly gone & unaltered \\
tryptophane & very strong & strong & strong & marked & faint
\end{tabular}

The fibrin remained unaltered in No. 5 after further digestion for 48 hours : the tryptophane-reaction had then become distinct.

These results show that an addition of $\mathrm{HCl}$ to $0.4 \%$ is about the limit of acidity for both fibrin-digestion and peptolysis for an extract of this degree of concentration: but as the differentiation was inconclusive, I made another experiment with more dilute extract, and with stronger alkali.

$3 \circ \mathrm{grms}$. of bulb were extracted with $200 \mathrm{cc} .2 \% \mathrm{NaCl}$-solution, to which $4 \mathrm{grms}$. of Witte-peptone were added, and $\mathrm{HCN}$ to $0.16 \%$ : $40 \mathrm{cc}$. were put into each of 5 bottles, with $0.2 \mathrm{grm}$. fibrin, as follows:-No. I, natural acidity; No. $2, \mathrm{Na}_{2} \mathrm{CO}_{3}$ to $2 \%$; No. $3, \mathrm{Na}_{2} \mathrm{CO}_{3}$ to $3 \%$; No. $4, \mathrm{Na}_{2} \mathrm{CO}_{3}$ to $4 \%$; No. 5 , $\mathrm{HCl}$ to $0.2 \%$.

After 24 hours' digestion the results were :-

$\begin{array}{llllll} & \text { I. } & 2 . & 3 \cdot & 4 \cdot & 5 \cdot \\ \text { fibrin } & \text { gone } & \text { gone } & \text { gone } & \text { unaltered } & \text { unaltered } \\ \text { tryptophane } & \text { strong } & \text { strong } & \text { marked } & \text { distinct } & \text { marked }\end{array}$

after 48 hours' digestion the results were :-

$\begin{array}{llllll}\text { fibrin } & - & - & - & \text { partly gone } & \text { unaltered } \\ \text { tryptophane } & \text { very strong } & \text { strong } & \text { strong } & \text { strong } & \text { very strong }\end{array}$

Conclusion: the limit of alkalinity for peptolysis had not yet been reached, but its retarding effect is clear : the limits of alkalinity and of acidity for fibrin-digestion 
are indicated : the reaction-range of peptolysis is wider than that of fibrin-digestion, though they both are wide.

Even in this experiment the differentiation is not so marked as might be desired: but it suffices to show that here, as in the case of Yeast, fibrin-digestion is more readily affected than peptolysis by increased acidity or by alkalinity.

\section{Nepenthes.}

In a previous paper $(16$, p. 570$)$ I showed that pitcher-liquid not only digests fibrin in acid reaction $(0.3 \% \mathrm{HCl})$, but also effects peptolysis as indicated by the tryptophane-reaction. The following are some recent experiments made with a view to differential action. The liquid used was obtained from various species, and was neutral.

To 60 cc. of the liquid I grm. of Witte-peptone was added, and $\mathrm{HCN}$ to $0.2 \%$ : $20 \mathrm{cc}$. were put into each of 3 bottles, with $0.2 \mathrm{grm}$. fibrin, treated as follows:-No. I, $\mathrm{Na}_{2} \mathrm{CO}_{3} 0.5 \%$; No. $2, \mathrm{HCl} 0.2 \%$; No. $3, \mathrm{HCl} 0.5 \%$.

After 24 hours' digestion $\left(40^{\circ} \mathrm{C}\right.$.) the results were:-

I. 2.

$\begin{array}{llll}\text { fibrin } & \text { unaltered } & \text { partly gone } & \text { gone } \\ \text { tryptophane } & \text { faint } & \text { distinct } & \text { faint }\end{array}$

0.2 grm. Witte-peptone now added to each bottle, and after 24 hours' further digestion the results were :-

\begin{tabular}{llll} 
fibrin & \multicolumn{1}{c}{ I. } & \multicolumn{1}{c}{2.} & 3. \\
tryptophane & faint & distinct & gone \\
marked
\end{tabular}

Bottle No. I was further digested for 96 hours, when a marked tryptophanereaction was obtained; the fibrin remaining unaltered.

This experiment brought to light the new and important fact that Nepenthes-liquid can effect peptolysis in an alkaline liquid. With a view to confirmation the following experiments were made.

$20 \mathrm{cc}$. of pitcher-liquid were put into each of 2 bottles, to each of which were added $\mathrm{HCN}$ to $0.2 \%$, Witte-peptone $0.4 \mathrm{grm}$., and $0.1 \mathrm{grm}$. of fibrin : the contents of both bottles were made alkaline to the extent of 0.25 in the one case, of 0.15 in the other. After 48 hours' digestion the results were :-

$\begin{array}{lll} & 0.25 \mathrm{Na}_{2} \mathrm{CO}_{3} . & \text { O.15 } \mathrm{Na}_{2} \mathrm{CO}_{3} . \\ \text { fibrin } & \text { unaltered } & \text { unaltered } \\ \text { tryptophane } & \text { none } & \text { none }\end{array}$

after 48 hours' further digestion:-

$\begin{array}{lll}\text { fibrin } & \text { unaltered } & \text { unaltered } \\ \text { tryptophane } & \text { faint } & \text { distinct }\end{array}$

In another similar experiment, I obtained distinct tryptophane-reactions in liquids containing $0.5 \%, \mathrm{I} \%$, and $\mathrm{I} \cdot 5 \% \mathrm{Na}_{2} \mathrm{CO}_{3}$ after $\mathrm{I} 44$ hours' digestion. 
The following experiment may be given in full. $50 \mathrm{cc}$. of neutral pitcher-liquid were made alkaline by the addition of $\mathrm{Na}_{2} \mathrm{CO}_{3}$ to $0.4 \%$ : I grm. of Witte-peptone was added, and $\mathrm{HCN}$ to $0.2 \%$. I 0 cc. of the liquid were boiled and put into a separate bottle as a control. After 96 hours' digestion the boiled and the unboiled liquids were separately evaporated to half-bulk: the unboiled liquid then gave a marked tryptophane-reaction, the boiled liquid only a faint reaction.

Conclusion: the pitcher-liquid peptonizes fibrin much more rapidly than it peptolyses Witte-peptone: fibrin-digestion inhibited by alkalinity, promoted by acidity; the limit of acidity was not reached: peptolysis, slow in any case, much retarded by alkalinity, but not inhibited by small percentage of alkali that arrested fibrin-digestion.

The fact that fibrin-digestion is so much more active than peptolysis, suggests at once the presence of two proteases; for, were there a single 'tryptic' protease, both digestive processes should be equally active : and further, that the ereptase is present in relatively small quantity. In its general proteolytic action, the liquid does not agree exactly with any of the other juices or extracts : in its reaction-range for fibrin-digestion it resembles the extracts of Yeast, Mushroom, and Malt, though with a higher $\mathrm{HCl}$-limit : in its reaction-range for peptolysis it resembles papaïn, Pineapple juice, and extracts of Hyacinth-bulb. The subject requires further investigation: but for lack of a supply of pitcher-liquid I cannot pursue it at present, though I hope to do so later in the year. However, the results now given show a divergence in the reaction-ranges for fibrindigestion and peptolysis sufficiently marked to suggest the presence of two proteases.

\section{Summary and Conclusion.}

The experiments detailed in the foregoing pages constitute a demonstration of the differential effect of varied reaction upon the proteolytic activities of the juices and extracts of certain representative plants. In endeavouring to bring the facts together, it must be recognized that they are not capable of close comparison on account of the different chemical composition of the juices and extracts, and, more especially, of the difference of their initial reactions, two only being neutral (papaïn, Nepenthes-liquid), the rest more or less strongly acid. Nevertheless, it is possible to make a few general statements. Taking peptolysis first, it appears that it always took place within a range extending from distinct alkalinity to a degree of acidity beyond the natural : the difference between the individual cases is thus one of degree only. Fibrin-digestion, on the other hand, was much less uniform, showing such wide and striking differences that it is possible to arrange the individual cases into two groups, thus:-

(a) those in which it was limited to acid reaction: Yeast, Mushroom, Malt, Nepenthes. 
(b) those in which it also occurred with alkaline reaction: papain, Pineapple, Hyacinth-bulb.

Moreover, in the latter group, fibrin-digestion proceeded when the alkalinity was relatively strong: papain, $\mathrm{I} \cdot 5 \% \mathrm{Na}_{2} \mathrm{CO}_{3}$; Pineapple, acid liquid to which $8 \% \mathrm{Na}_{2} \mathrm{CO}_{3}$ had been added; Hyacinth, acid liquid to which $3-4 \% \mathrm{Na}_{2} \mathrm{CO}_{3}$ had been added. Out of all this diversity one inference of fundamental importance can immediately be drawn, namely this, that in every case it is at natural acidity that both fibrin-digestion and peptolysis are active; this is their point of coincidence.

On further consideration of these results, it will, I think, be generally admitted that the method employed does actually afford the means of realizing that separation of the proteolytic activities which I postulated in the introduction (see p. 174) as being essential to the investigation of the nature of the supposed 'vegetable trypsin.' I cannot interpret the evidence thus obtained otherwise than as indicating that peptolysis and fibrindigestion are effected by two distinct proteases: that 'vegetable trypsin' is, in fact, not a single protease, but a mixture of two ; the one a peptolytic enzyme belonging to the ereptases, the other a peptonizing, fibrin-digesting enzyme belonging to the peptases. I do not term the ereptic enzyme simply 'erepsin,' or the fibrin-digesting enzyme 'pepsin,' because these terms have been specifically applied to the proteases of animals, and because the properties are not identical in either case: thus 'vegetable erepsin' differs from animal erepsin in that it is active through a wider range of both acid and alkaline reaction, whilst the latter (at least in the case of the higher animals) is inactive in the presence of acid; and 'vegetable pepsin' can, in certain cases at least, act in an alkaline medium, whilst animal pepsin cannot. Neither the erepsins nor the pepsins of animals and plants are identical. It is convenient to regard the different kinds of erepsin as members of the group of ereptases, as being, as it were, species of the genus: similarly the pepsins form the group of peptases. Ereptases and peptases belong to the larger group of proteases, as being enzymes capable of acting upon proteid substances.

The fact that the ereptase occurs alone, so far as I have been able to discover, in many plants, notably in leaves, makes, as I have already urged, in favour of the view that all peptolytic action in plants is due to this enzyme. The position would be materially strengthened if, in the course of investigation, cases of the independent existence of the peptase were likewise to be brought to light. But this has not yet been done; and the fact that wherever fibrin-digestion has been observed it has always been found to be accompanied by peptolysis, remains to provide an argument of some weight against the view of the autonomy of the two enzymes that I have been led to adopt. The only immediate reply to this objection is the fairly obvious one, that a merely peptonizing enzyme alone would be 
of little use to the plant. The significance of the proteases in the economy is that they facilitate the translocation of organic nitrogen in the form of readily diffusible substances. This end is fully attained when the proteolysis is such as to produce from indiffusible proteids bodies like leucin, tyrosin, \&c., but only imperfectly when it goes no further than the formation of albumoses and peptones. These facts and considerations also supply the material for an answer to Martin's question on p. I73, and, it may be added, are as applicable in the case of animals as in that of plants.

The duality of the enzymes is the main point to be determined, but it is by no means the only point: the wide differences in reaction-range both of peptolysis and of fibrin-digestion exhibited by the various juices and extracts have yet to be considered. How is the fact to be accounted for that peptolysis is retarded in the case of papain, Pineapple juice, and Nepenthes-liquid by a degree of alkalinity that in the other cases has little or no effect; or the fact that fibrin-digestion is practically limited to acid reaction in the case of Nepenthes, Yeast, Mushroom, and Malt, whilst it is actively carried on in alkaline liquid by papaïn, Pineapple juice, and extract of Hyacinth-bulb? A possible explanation would be that the proteases are not of the same kind in the two sets of cases. On the hypothesis of a single 'tryptic' protease it might be supposed that there exist several varieties of the protease. Similarly on the hypothesis of two proteases, an ereptase and a peptase, it might be supposed that varieties of ereptases and peptases exist in the different plants. But this is not the only possible explanation: another may be suggested, based not upon qualitative but on quantitative differences. I have found, in previous experiments with Yeast (4), that differences in the zymotic strength of an extract are accompanied by differences in its reaction-range: that, for instance, a degree of alkalinity that sufficed to inhibit fibrin-digestion by a $5 \%$ Yeast-liquid had little or no effect upon a $10 \%$ liquid. Quantity is therefore a factor in the problem: but, in view of the foregoing experimental results, the quantitative explanation is only applicable on the hypothesis of two proteases. Although the available facts are perhaps insufficient to settle finally the question as between the qualitative and the quantitative explanations-for these researches do not amount to more than pioneer-work-yet in some respects they distinctly support the latter. Thus the peptolytic results are on the whole so uniform, with a common range extending from distinct alkalinity to distinct acidity, that-if allowance be made for the incidental differences in the chemical composition of the various juices and extracts-there is no sufficient reason for attributing the observed differences in reaction-range to a distinct ereptase in each case. These differences may be more reasonably ascribed to variations in the quantity of one and the same ereptase: the reaction-range 
may be taken as indicating the relative amount of ereptase in the individual cases.

The results of fibrin-digestion, being so divergent, are more difficult to deal with. As I have already pointed out (see p. I 84), these results fall naturally into two groups: those obtainable through a wide range of reaction from alkalinity to acidity; those limited to acidity. It does not appear possible, at present, to attribute this marked divergence wholly to variations in the quantity of one and the same peptase: it seems to indicate difference in kind rather than in degree. It may be that there are in plants two varieties of peptases more adapted respectively to acid or to alkaline reaction. The decision must be left to more extended and exact experiments than I have yet been able to make.

If it be admitted that two proteases or two groups of proteases exist in plants, the ascertained facts as to the distribution of the proteases in the vegetable kingdom may be succinctly stated in the following propositions : -all plants that have been examined contain ereptase: in some of these plants the ereptase has been found to be associated with a larger or smaller proportion of a peptase: in no plant has a peptase been found to exist unassociated with ereptase.

\section{List of PAPERS REFERRED TO.}

1. VINes : Tryptophane in Proteolysis; Annals of Botany, vol. xvi, March, I902, p. I.

2. —_: Proteolytic Enzymes in Plants ; ibid., vol. xvii, January, 1903, p. 237.

3. - : Proteolytic Enzymes in Plants (II); ibid., June, I903, p. 597.

4. - : Proteases of Plants; ibid., vol. xviii, April, r904, p. 290.

5. : : Proteases of Plants (II); ibid., vol. xix, Jan. 1905, p. I 49.

6. DARWIN : Insectivorous Plants, I875, p. $30 \mathrm{I}$.

7. Hooker : Address to the Department of Zoology and Botany of the British Association, Belfast Meeting, I874.

8. VON GORUP-BESANEZ UND WiLl: Fortgesetzte Beobachtungen über peptonbildende Fermente im Pflanzenreiche; Sitzber. der physik.-med. Soc. zu Erlangen, 1876.

9. von GORUP-BESANEZ: Weitere Beobachtungen über diastatische und peptonbildende Fermente im Pflanzenreiche; ibid., I875.

10. Wurtz: Recherches cliniques et chimiques sur la papaine; Paris Médical, 1879.

11. Martin : Papaïn-digestion; Journ. of Physiol., vol. v, I884, p. 230.

12. ㄴ : The Nature of Papain and its Action on Vegetable Proteid; ibid., vol. vi, 1885, p. 360.

13. Green : On the Changes in the Proteids of Seeds which accompany Germination; Phil. Trans., vol. clxxviii B, I887, p. 58 .

14. Chittenden: On the Ferments contained in the Juice of the Pine-Apple; Trans. Connecticut Acad., vol. viii, 1891 , p. 26.

15. Clautriau : La Digestion dans les urnes de Nepenthes; Mém. couronnés, Acad. roy. de Belgique, vol. lix, 1900.

16. Vines: The Proteolytic Enzyme of Nepenthes (III) ; Annals of Botany, vol. xv, r9or, p. 569.

17. Mendel and Underhill: Observations on the Digestion of Proteids with Papain ; Trans. Connecticut Acad., vol. xi, I9or, p. I3.

18. Weis: Etudes sur les enzymes protéolytiques de l'orge en germination; Comptes-rendus des travaux du Laboratoire de Carlsberg, vol. v, 1903, p. 133 . 


\section{$2 \mathrm{BHL}$ Biodiversity Heritage Library}

Vines, Sydney Howard. 1905. "The proteases of plants (III)." Annals of botany 19, 171-187. https://doi.org/10.1093/oxfordjournals.aob.a088996.

View This Item Online: https://www.biodiversitylibrary.org/item/233541

DOI: https://doi.org/10.1093/oxfordjournals.aob.a088996

Permalink: https://www.biodiversitylibrary.org/partpdf/318794

\section{Holding Institution}

Smithsonian Libraries

\section{Sponsored by}

Biodiversity Heritage Library

\section{Copyright \& Reuse}

Copyright Status: Not in copyright. The BHL knows of no copyright restrictions on this item.

This document was created from content at the Biodiversity Heritage Library, the world's largest open access digital library for biodiversity literature and archives. Visit BHL at https://www.biodiversitylibrary.org. 